\title{
The Relationship between Secondary School Students' Lifelong Learning Tendencies and Attitudes towards English Lesson as a Foreign Language*
}

\author{
Arzu ASLITÜRK ${ }^{* *}$
}

\author{
Subhan EKŞİOĞLU**
}

\begin{abstract}
In this study, it is aimed to examine the lifelong learning tendencies of secondary school students and their attitudes towards English as a foreign language and whether there are differences in terms of gender, grade level and school type between two structures. The sample of the study is composed of 744 students, 358 female and 386 male students selected from seven secondary schools by cluster sampling in 2017-2018 academic year, in the secondary schools in Kaynarca district of Sakarya province. Correlational survey model was used to examine these relationships. The 17-item Lifelong Learning Trends Scale developed by Gür-Erdoğan and Arsal (2016) was used to measure participants' lifelong learning tendencies. In order to measure the attitudes of the participants towards the English course, a 30-item Attitudes towards English Scale, which was developed by Hanci-Yanar (2008), was used. In the study, there was a moderate significant relationship between students' lifelong learning tendencies and attitudes towards English course as a foreign language.
\end{abstract}

Keywords: Lifelong Learning, Tendency, Foreign Language, English, Attitude.

\footnotetext{
* This study was produced from the first author's master's thesis, which was conducted under the supervision of the second author.

Ethics committee approval for this study was obtained from the Ethics Committee of Sakarya University Rectorate, dated 27/02/2018 and numbered 81.

** Orcid ID: https://orcid.org/0000-0001-6736-8895, Master Student, Sakarya University, Educational Curriculum and Instruction, Turkey, arzuasliturk@hotmail.com

*** Orcid ID: https://orcid.org/0000-0002-5471-627X, Assist. Prof. Dr., Sakarya University, Educational Curriculum and Instruction, Turkey, eksioglu@sakarya.edu.tr
}

Aslıtürk, A., \& Ekşioğlu, S. (2020). The Relationship between Secondary School Students' Lifelong Learning Tendencies and Attitudes towards English Lesson as a Foreign Language, Sakarya University Journal of Education, 10(3), 609-622. doi: https://doi.org/10.19126/suje.815121 


\section{INTRODUCTION}

Lifelong learning is based on the philosophy that individual's motivation to learn throughout his/her life, to actively participate in learning activities and to develop selflearning skills in the individual. European societies build their educational policies and professional advances on human-oriented practices and try to embody the phenomenon of lifelong learning with these policies (Toprak \& Erdoğan, 2012: 70). Each society has different applications within the scope of lifelong learning. While some countries consider lifelong learning within the scope of adult education; some countries see this concept as continuing education and carry out studies covering all individuals without addressing any age group.

In Turkey, lifelong learning activities have been added to the agenda with the process of entering the European Union candidacy and with the impact of advances in technology, issues addressing the 21st century such as gaining life skills, manpower training, and digital literacy have come to the fore. Therefore, giving education only to a certain audience at certain time intervals was insufficient to meet the needs required to reach social welfare; it has become mandatory for individuals to renew and update their knowledge, skills and competencies, and development plans in which the country's goals are set in the long term have been prepared by considering lifelong learning strategies.

Considering the importance and value that countries place on information technologies and the service sector; it is noticed that the changes in education are directed in line with these demands and needs. Because of that; individuals should be equipped with skills such as effective problem solving, critical thinking, and computer literacy. Particularly, individuals who are outside the scope of formal education to have these skills and competencies can become possible through the lifelong education process (MEB, 2009, as cited in Adabaș, 2016: 10).

Holistic approaches in the field of education also support the concepts of globalization, diversity, tolerance, respect and self-awareness. Effective foreign language teaching aims to create a more peaceful and democratic world order by bringing these concepts to the individual, and realizing this teaching depends on the development of lifelong learning awareness (Can, 2011). Although it is accepted by the researchers that the beliefs and attitudes of individuals about foreign language have an effect on increasing or preventing success, there are very few studies investigating this subject in different age groups, educational institutions and in the context of lifelong learning (Kaçar \& Zengin, 2009: 58). However; the individual always interacts with the environment and society, consciously or unconsciously. As a result of this interaction, the individual's thoughts, behaviors, skills and perceptions are constantly being renewed and changed. However, the idea that education and training cover only children and youth constitute an important obstacle for the development of the lifelong learning concept (Akın, 2016: 27). At the same time, knowing the individual's attitude towards foreign language in the education process and arranging the language teaching program accordingly have an effect that will increase the efficiency and success in terms of the quality of education (Karatay and Kartallığlu, 2016: 
206). In today's world, when the knowledge of foreign languages is becoming more and more important, it is important to examine the relationship between the attitudes of individuals towards foreign language and their lifelong learning tendencies in terms of guiding the studies to be carried out on this subject. In this context, in this study, it is aimed to determine whether there is a relationship between the lifelong learning tendencies of secondary school students and their attitudes towards English lesson. "Is there a relationship between secondary school students' lifelong learning tendencies and their attitudes towards English as a foreign language?" the answer to the question was sought and it was tried to determine whether this relationship varies according to the gender of the students, grade level and the type of school they study.

\section{METHOD}

This study examines the relationship between secondary school students' lifelong learning tendencies and their attitudes towards English as a foreign language. Therefore, it is modeled with a correlational survey model.

\section{Population and Sample}

The population of the study is the fifth, sixth, seventh and eighth grade students studying in secondary schools in the district of Kaynarca in Sakarya Province in the 2017-2018 academic year. The sample consists of 744 students selected through cluster sampling method. 358 (48.1\%) of the students are girls and 386 (51.9\%) are boys. 535 (71.9\%) of the students' study in general secondary school, 209 (28.1\%) in Imam Hatip secondary school. There are 147 (19.8\%) in the 5th grade, 274 (36.8\%) in the 6th grade, $160(21.5 \%)$ in the 7 th grade, and $163(21.9 \%)$ in the 8 th grade.

\section{Data Collection Tools}

Demographic information questions, the 17-item prepared in five-point likert type "Lifelong Learning Trends Scale (LLLTS)", developed by Gür-Erdoğan and Arsal (2016), and 30-items prepared in five-point likert type "Attitudes towards English Scale (AES)", developed by Hancl-Yanar (2008), were used as data collection tools in the study. Cronbach alpha value of the reliability coefficient of Lifelong Learning Trends Scale (LLLTS) was found to be .90 and Attitudes towards English Scale (AES) was found to be .92.

As a result of the Confirmatory Factor Analysis (CFA), it was seen that the values calculated for the two-dimensional structure of LLLTS are among the good fit and acceptable fit values. All values for the three-dimensional structure tested for AES were found to be within the limits of acceptable fit values. Accordingly, it can be said that both LLLTS and AES are valid measurement tools for the applied group. Ethics committee approval for this study was obtained from the Ethics Committee of Sakarya University Rectorate, dated 27/02/2018 and numbered 81. 


\section{Data Collection and Analysis}

In the analysis of the data, the normality tests (Kolmogorov-Simirnov and Shapiro-Wilk) were performed first. It was determined that the data did not show normal distribution and therefore Mann-Withney $U$ and Kruskal-Wallis tests were used in the analysis of the data. Spearman Rho correlation coefficient was used to calculate the relationship between lifelong learning tendencies and the attitudes towards English as a foreign language.

\section{FINDINGS}

The first of the findings from the analysis of the data obtained from the research relates to the level of students ' lifelong learning tendencies and attitudes towards English.

In order to determine the level of secondary school students ' lifelong learning tendencies and attitudes towards English, descriptive statistics for the total scores of LLLTS and AES have been calculated and their values are presented in Table 1.

Table 1

Descriptive Statistics on LLLTS and AES Total Scores

\begin{tabular}{lccccccc}
\hline & $\mathrm{N}$ & $\overline{\mathrm{X}}$ & $\begin{array}{c}\text { Std. Art. } \\
\text { Mean }\end{array}$ & Median & Std. Dev & Min. & Max. \\
& & & & & & \\
\hline $\begin{array}{l}\text { Lifelong } \\
\text { Learning }\end{array}$ & 744 & 66.074 & 3.887 & 68.00 & 11.736 & 17.00 & 85.00 \\
$\begin{array}{l}\text { Tendency } \\
\begin{array}{l}\text { Attitude towards } \\
\text { English }\end{array}\end{array}$ & 744 & 107.376 & 3.579 & 107.00 & 21.907 & 17.00 & 85.00 \\
\hline
\end{tabular}

When the arithmetic averages are examined according to Table 1, the arithmetic mean of the Lifelong Learning Tendency is 66.074. The arithmetic mean of the Attitude towards English is 107.376. Considering the values belonging to the 5-point Likert-type categories, it shows that the majority of secondary school students tend to "agree" in both LLLTS and AES.

In this study, it was aimed to determine whether different variables affect secondary school students ' lifelong learning tendencies and attitudes towards English. Firstly, an answer was sought for the question of whether the lifelong learning tendencies of the secondary school students and their attitudes towards English differ in terms of gender. In this context, Mann-Withney U test was performed to compare the scores of female and male students and the results related to this test are presented in Table 2. 
Table 2

Mann-Whitney U Test Results of Lifelong Learning Tendency and Attitudes towards English in terms of Gender

\begin{tabular}{llllllll}
\hline & Gender & $\mathrm{N}$ & $\begin{array}{l}\text { Mean } \\
\text { Rank }\end{array}$ & $\begin{array}{l}\text { Sum of } \\
\text { Rank }\end{array}$ & & U \\
\hline Lifelong Learning & Female & 358 & 406.34 & 145470.50 & 56978.50 & $0.000^{*}$ \\
Tendency & Male & 386 & 341.11 & 131669.50 & & \\
\hline $\begin{array}{l}\text { Attitude towards } \\
\text { English }\end{array}$ & Female & 358 & 429,64 & 153811,50 & 48637,500 & $0.000^{*}$ \\
& Male & 386 & 319,50 & 123328,50 & & \\
\hline
\end{tabular}

$* p<0.05$

When Table 2 was analyzed, it was observed that the mean rank of female students in both LLLTS and AES were higher than mean rank of male students. As a result of the MannWhitney U test conducted to compare these mean ranks, a significant difference was found between the scores of female and male students in their lifelong learning tendencies $(\mathrm{U}=$ 56978.50, $\mathrm{p}<0.05)$ and their attitudes towards English $(U=48637,500, \mathrm{p}<0.05)$. This can be interpreted as a situation in favor of female students, both in terms of lifelong learning tendency and attitude towards English.

Another question in which the answer was sought in the study was: "Do the lifelong learning tendencies of secondary school students and their attitudes towards English differ in terms of grade level? In this context, in order to compare the scores of 5th, 6 th, 7 th and 8th grade students, Kruskal-Wallis test was performed and the results related to this test are presented in Table 3.

Table 3

Kruskal-Wallis Test Results of Lifelong Learning Tendency and Attitudes towards English in terms of Grade Level

\begin{tabular}{|c|c|c|c|c|c|c|c|c|}
\hline & $\begin{array}{l}\text { Grade } \\
\text { Level }\end{array}$ & $\mathrm{N}$ & $\begin{array}{l}\text { Mean } \\
\text { Rank }\end{array}$ & S.d. & $\chi^{2}$ & $p$ & Difference & \\
\hline \multirow{4}{*}{$\begin{array}{l}\text { Lifelong } \\
\text { Learning } \\
\text { Tendency }\end{array}$} & $5^{\text {th grade }}$ & 147 & 424.46 & 3 & 15.927 & $0.001 *$ & $5^{\text {th grade }}$ & - \\
\hline & & & & & & & $7^{\text {th grade }}$ & \\
\hline & $6^{\text {th }}$ grade & 274 & 379.72 & & & & $\begin{array}{l}5^{\text {th }} \text { grade } \\
8^{\text {th }} \text { grade }\end{array}$ & - \\
\hline & $7^{\text {th }}$ grade & 160 & 331.86 & & & & & \\
\hline
\end{tabular}




\begin{tabular}{|c|c|c|c|c|c|c|c|c|}
\hline & $8^{\text {th }}$ grade & 163 & 353.40 & & & & & \\
\hline \multirow{5}{*}{$\begin{array}{l}\text { Attitude } \\
\text { towards } \\
\text { English }\end{array}$} & $5^{\text {th grade }}$ & 147 & 442,44 & 3 & 31,711 & $0.000^{*}$ & \multirow{2}{*}{$\begin{array}{l}5^{\text {th grade }} \\
7^{\text {th }} \text { grade }\end{array}$} & - \\
\hline & $6^{\text {th }}$ grade & 274 & 388,43 & 3 & 31,711 & $0.000 *$ & & \\
\hline & $7^{\text {th }}$ grade & 160 & 333,26 & & & & $\begin{array}{l}5^{\text {th }} \text { grade } \\
8^{\text {th }} \text { grade }\end{array}$ & - \\
\hline & $8^{\text {th grade }}$ & 163 & 321,17 & & & & $\begin{array}{l}6^{\text {th }} \text { grade } \\
8^{\text {th }} \text { grade }\end{array}$ & - \\
\hline & & & & & & & $\begin{array}{l}5^{\text {th }} \text { grade } \\
7^{\text {th }} \text { grade }\end{array}$ & - \\
\hline
\end{tabular}

$* p<0.05$

When Table 3 is examined, the mean ranks in terms of lifelong learning tendencies are ranked from largest to smallest as 5th grade (424.46), 6th grade (379.72), 8th grade (353.40) and 7th grade (331.86). Considering the life-long learning tendency mean ranks, the highest averages were in the 5 th grade and the lowest averages in the 7 th grade. According to the results of Kruskal-Wallis test conducted to compare this difference in mean ranks, a significant difference was found in students' lifelong learning tendencies $(\chi 2(3)=15.927, p<0.05)$ in terms of grade level. In the paired comparisons made to find out between which grades these differences arise in cases where significant differences occur, the difference arises in favor of 5 th grade between 5 th grade and 7 th grade; it is in favor of 5th grade between 5th grade and 8th grade. The mean rank of attitude towards English ranges from largest to smallest is in the form of 5th grade $(442,44), 6$ th grade $(388,43), 7$ th grade $(333,26)$ and 8 th grade $(321,17)$. Considering the mean ranks, the highest averages were in the 5 th grade and the lowest averages in the 8th grade. According to the results of Kruskal-Wallis test conducted to compare these differences in mean ranks, a significant difference was found in students' attitude towards English $(\chi 2$ (3) $=31,711, p<0.05$ ) in terms of grade level. In the paired comparisons made to find out between which grades these differences arise in cases where significant differences occur, there is a significant difference between the 5th grade - 7th grade and 5th grade - 8th grade in terms of attitudes towards English and this difference is in favor of 5th grade in both cases; the significant difference between 6th grade and 8th grade was in favor of 6th grade.

In the study, it was investigated whether the lifelong learning tendencies of the secondary school students and their attitudes towards English differ in terms of school type and Mann-Withney U test was performed to compare the students' scores and the results related to this test are presented in Table 4. 
Table 4

Results of Mann-Withney $U$ test of Lifelong Learning Tendency and Attitudes towards English in terms of School Type

\begin{tabular}{|c|c|c|c|c|c|c|}
\hline & $\begin{array}{l}\text { School } \\
\text { Type }\end{array}$ & $\mathrm{N}$ & $\begin{array}{l}\text { Mean } \\
\text { Rank }\end{array}$ & $\begin{array}{l}\text { Sum of } \\
\text { Rank }\end{array}$ & $\mathrm{U}$ & $P$ \\
\hline \multirow[t]{2}{*}{$\begin{array}{l}\text { Lifelong Learning } \\
\text { Tendency }\end{array}$} & $\begin{array}{l}\text { Secondary } \\
\text { School }\end{array}$ & 535 & 368,06 & 196912,50 & 53532,500 & 0.367 \\
\hline & İHSS & 209 & 383,86 & 80227,50 & & \\
\hline \multirow[t]{2}{*}{$\begin{array}{l}\text { Attitude towards } \\
\text { English }\end{array}$} & $\begin{array}{l}\text { Secondary } \\
\text { School }\end{array}$ & 535 & 346,20 & 185216,00 & 41836,000 & $0.000^{*}$ \\
\hline & İHSS & 209 & 439,83 & 91924,00 & & \\
\hline
\end{tabular}

$* p<0.05$

When Table 4 is analyzed, it is seen that the mean rank of imam hatip secondary school students is higher than the average of secondary school students in terms of lifelong learning tendencies and attitude towards English. As a result of the Mann-Whitney U test conducted to compare these mean ranks, no significant difference was found between the scores of secondary school and imam hatip secondary school students in their lifelong learning tendencies $(\mathrm{U}=53532.50, \mathrm{p}>0.05)$. In their attitudes towards English $(\mathrm{U}=$ $41836,000, p<0.05$ ), a significant difference was found between the scores of secondary school and imam hatip secondary school students. In terms of attitudes towards English, it can be interpreted as a situation in favor of imam hatip secondary school students.

Finally, the Spearman Rho correlation coefficients of LLLTS and AES were calculated in order to examine whether there is a relation between the lifelong learning tendencies of the secondary school students and their attitudes towards English.

Table 5

The Relationship between Lifelong Learning Tendency and Attitudes towards English

\begin{tabular}{lll}
\hline & $\begin{array}{l}\text { Openness to } \\
\text { Development }\end{array}$ & Lifelong Learning Tendency \\
\hline Lifelong Learning Tendency & 1 & $0.499^{*}$ \\
Attitude towards English & $0.499^{*}$ & 1 \\
\hline
\end{tabular}


According to Table 5, it was observed that there is a moderate significant ( $\mathrm{rs}=0.499, \mathrm{p}$ $<0.01$ ) relationship between secondary school students' lifelong learning tendency and their attitudes towards English.

\section{RESULTS, DISCUSSIONS AND SUGGESTIONS}

The fact that the majority of secondary school students tend to "agree" on the whole scale showed that their lifelong learning tendencies are high. According to this result of the research, it can be said that the students have a good level of lifelong learning tendencies, they enjoy learning new things and they give importance to progress in their professional careers. In the literature review of the related field, studies with similar results were not found due to the limited number of studies on the lifelong learning tendencies of secondary school students. However, Diker Coşkun and Demirel (2012) stated in their studies that university students' lifelong learning tendencies were at a medium level. Kozikoğlu and Altunova (2018) stated in their study that prospective teachers have a very high level of lifelong learning. When the attitudes of the students towards English as a foreign language course are examined, the fact that the majority of students turn to the answer "I agree" on the whole scale revealed that the students' attitudes towards English as a foreign language are positive. Studies conducted by Firat (2009), Memduhoğlu and Kozikoğlu (2015), Kazazoğlu (2011), Kızıltan and Atlı (2013) and Selçuk (1997) also found that the majority of students had positive attitudes.

When the lifelong learning tendencies of students and their attitudes towards English were examined in terms of gender variable, a significant difference was found between the average scores of male and female students. This difference is in favor of female students on both scales. In the literature of lifelong learning tendency, it was determined that the results obtained in terms of gender were consistent with this study in the studies conducted by Gencel (2013), Horuz (2017), İzci and Koç (2012), Kılıç (2014) and Kılıç (2015). In studies conducted by Yaman and Yazar (2015) and Ayaz (2016), it was concluded that, unlike this study, gender does not affect lifelong learning tendency. In the study conducted by Kılıç and Taşpınar (2017), the lifelong learning tendencies of both male and female participants were determined to be at a good level. In the attitude towards English, Bağceçi (2004), Genç and Aksu (2004) and Tok (2010) have reached conclusions that support the findings of the current research. Similarly, Inal, Evin and Saracaloğlu (2005) stated that students' attitudes towards learning foreign languages differ in terms of gender.

There was a significant difference in lifelong learning tendencies and attitudes towards English according to students' grade levels. Significant difference in lifelong learning tendency is in favor of 5th grade students. Accordingly, it can be concluded that the students who have completed primary school and passed to the secondary school level are more willing and enthusiastic about learning and have a higher lifelong learning tendency due to their efforts to prove themselves. The results of the studies performed by 
Diker Coşkun and Demirel (2012), and Kılıç (2014) coincide with this study. Karaduman (2015), on the other hand, concluded that the grade level variable does not make a significant difference in the lifelong learning tendencies of the students. In the attitude towards English, significant differences were observed in favor of 5th and 6th grades. It is observed that foreign language attitudes of younger groups are more positive. In the studies conducted by Anbarlı-Kırkız (2010) and Genç and Kaya (2011), conclusions supporting this study were obtained.

When the lifelong learning tendencies of the students are analyzed in terms of school type variable; there was no significant difference in lifelong learning tendencies between secondary school and imam hatip secondary school students. In the studies conducted by Diker Çoşkun (2009), Gencel (2013) and İzci and Koç (2012), it was concluded that the lifelong learning tendencies of the students differ according to the institution they are studying. In the studies conducted by Karaduman (2015), Kılıç and Taşpınar (2017) and Oral and Yazar (2015), it was determined that lifelong learning tendency did not differ in terms of the institution in which the education was studied. When it was examined whether their attitudes towards English differed in terms of school type, it was seen that attitude scores towards English resulted in favor of imam hatip secondary school students. It is thought that the reason for this is that Arabic as a foreign language is taught in imam hatip secondary schools and as a result, students' awareness of the foreign language may be reflected in their attitudes. In the study conducted by Akalın and Zengin (2007), it was determined that the foreign language attitudes of students studying in Imam hatip secondary and high schools were positive.

This study aims to determine whether there is a significant relationship between students' lifelong learning tendencies and their attitudes towards English as a foreign language. In this context, the relationship between lifelong learning and attitude towards English was also examined. In the light of the findings, it has been determined that there is a moderate meaningful relationship between students' lifelong learning tendencies and their attitudes towards English. When all these results are evaluated together, it can be concluded that lifelong learning tendencies of secondary school students and attitude towards English lessons support each other. In other words, the high level of lifelong learning tendency affects foreign language attitudes positively. In the literature review, no study investigating the relationship between lifelong learning tendencies directly at secondary school level and the attitude towards English as a foreign language was found. However, in the study conducted by Cevher, Atagül and Enser (2016) and investigating the effect of lifelong learning tendency on Turkish acquisition as a foreign language, it was determined that individuals who learned a foreign language had a higher lifelong learning tendency.

In light of the results obtained from the study, the following can be suggested:

The individual's curiosity, willingness to learn and openness to development lead to the acquisition of new knowledge, skills and abilities and enable the individual to explore his or her own potential. Therefore, the effects of affective factors in language education can 
be taken into consideration and studies can be carried out both inside and outside the school for students to be lifelong learning individuals. In order to bring lifelong learning skills to the individual in a more planned and effective way, they can be added to education and training programs as a new course or acquisition.

According to the gender variable, the differences in both lifelong learning tendencies and foreign language attitudes of students are in favor of female students. In this context; activities, award-winning competitions, word tournaments and studies that appeal to male students can be conducted in order to turn male students ' attitudes into positive and increase their lifelong learning. At the same time, the areas where male students are more interested than female students can be included in English lessons using online and mobile technologies. Thus, male students can be motivated to learning activities by drawing their attention to the lesson.

Another result of the study is that younger students have a better level of lifelong learning and attitudes towards English. Based on this result, it can be said that the earlier education of the individual is started at an early age, the more positive feedbacks there will be. Therefore, the cognitive and affective characteristics of students and critical learning periods should be evaluated together in the planning and implementation stage of education and training; the concepts of attitude, motivation, tendency and lifelong learning, which are necessary to increase success, should be taken into consideration.

According to the results of the research, foreign language attitudes of imam hatip secondary school students were found to be more positive in the school type variable. It is assumed that imam hatip secondary schools have language classes and students learn Arabic together with English may have an effect on this outcome. For these reasons, summer schools can be opened for qualified foreign language education in all secondary school institutions, education can be supported with interactive materials, and textbooks can be designed to improve all language skills.

\section{References}

Adabaş, A. (2016). Bartın üniversitesi lisansüstü eğitim öğrencilerinin yaşam boyu öğrenmede anahtar yeterliklere sahip olma düzeyleri [Levels of Bartın University graduate students' key competences in lifelong learning]. Unpublished Masters' Thesis, Bartın University, Bartın.

Akalın, S., \& Zengin, B. (2007). Türkiye'de halkın yabancı dil ile ilgili algıları. [The Attitude of People towards Foreign Language in Turkey]. Journal of Language and Linguistics Studies, 3(1), 181200.

Akın, M. (2016). Kadınlarda yoksulluğun görünümü ve yaşam boyu öğrenmeye etkisi [The appearance of poverty in women and its effect on lifelong learning]. Unpublished Masters' Thesis, Bartın University, Bartın.

Anbarlı-Kırkız, Y. A. (2010). Öğrencilerin Ingilizce dersine ait tutumları ile akademik başarıları arasındaki ilişki [The relationship between students' attitudes towards the English course and their academic achievement]. Unpublished Masters' Thesis, Trakya University, Edirne. 
Ayaz, C. (2016). Öğretmenlerin yaşam boyu öğrenme eğilimlerinin bazı değişkenler açısından incelenmesi (Mardin ili örneği) [Examining teachers' lifelong learning tendencies in terms of some variables (Mardin province example)]. Unpublished Masters' Thesis, Bartın University, Bartın.

Bağçeci, B. (2004). Ortaöğretim kurumlarında İngilizce öğretimine ilişkin öğrenci tutumları (Gaziantep ili örneği) [Student attitudes towards English teaching in secondary education institutions (Gaziantep province example)]. XIII. Ulusal Eğitim Bilimleri Kurultayı. 6- 9 Temmuz 2004, İnönü Üniversitesi, Eğitim Fakültesi, Malatya.

Can, T. (2011). Yaşam Boyu Öğrenme Bağlamında Yabancı Dil Olarak İngilizce Ders Kitaplarında Strateji Kullanımı [Using Strategy in English as a Foreign Language Textbooks in the Context of Lifelong Learning], Unpublished Doctoral Dissertation, İstanbul University, İstanbul.

Cevher, Ö. Y. Atagül, Y. Y., \& Enser, R. (2016). Yaşam boyu öğrenme eğilimlerinin yabancı dil olarak Türkçe edinimine etkisi [The effect of lifelong learning tendencies on acquisition of Turkish as a foreign language]. International Journal of Human Sciences, 13(1), 277-284.

Diker Coşkun, Y. (2009). Üniversite öğrencilerinin yaşam boyu öğrenme eğilimlerinin bazı değişkenler açısından incelenmesi [Examining the lifelong learning tendencies of university students in terms of some variables]. Unpublished Doctoral Dissertation, Hacettepe University, Ankara.

Diker Coşkun, Y., \& Demirel, M. (2012). Üniversite öğrencilerinin yaşam boyu öğrenme eğilimleri [Lifelong learning trends of university students]. Hacettepe Üniversitesi Eğitim Fakültesi Dergisi, 42 (42), 108-120.

Firat, A. 2009. A study on young learners' attitudes towards learning English. Unpublished Masters' Thesis, Çukurova University. Adana.

Gencel, İ. E. (2013). Öğretmen adaylarının yaşam boyu öğrenme yeterliklerine yönelik algıları [Preservice teachers' perceptions of lifelong learning competencies]. Eğitim ve Bilim Dergisi, 38 (170), 237-252.

Genç, G., \& Aksu M. B. (2004). İnönü Üniversitesi öğrencilerinin İngilizce derslerine ilişkin tutumları [İnönü University students' attitudes towards English lessons]. XIII. Ulusal Eğitim Bilimleri Kurultayı. 6-9 Temmuz 2004, İnönü Üniversitesi, Eğitim Fakültesi, Malatya.

Genç, G., \& Kaya, A. (2011). Sınıf öğretmeni adaylarının yabancı dil derslerine yönelik tutumları ile yabancı dil akademik başarıları arasındaki ilişki [The relationship between classroom teacher candidates' attitudes towards foreign language courses and their foreign language academic achievements]. Balıkesir Üniversitesi Sosyal Bilimler Enstitüsü Dergisi, 14(26), 19-31.

Gür-Erdoğan, D., \& Arsal, Z. (2016). Yaşam boyu öğrenme eğilim ölçeği (YBÖEÖ)'nin geliștirilmesi [Development of the lifelong learning tendency scale (LLLTS)]. Sakarya University Journal of Education, 6(1), 114122.

Hancı-Yanar, B. (2008). Yabancı dil hazırlık eğitimi alan ve almayan Anadolu Lisesi öğrencilerinin yabancı dil özyeterlik algılarının ve Ingilizce dersine yönelik tutumlarının incelenmesi [Examination of the foreign language self-efficacy perceptions and attitudes towards the English course of Anatolian High School students who received and did not receive foreign language preparatory education]. Unpublished Masters' Thesis, Ege University, İzmir.

Horuz, O. R. (2017). Mesleki eğitim merkezi öğrencilerinin yaşam boyu öğrenme eğilimlerinin incelenmesi (Bartın ili örneği) [Investigation of lifelong learning tendencies of vocational education center students (Bartın province example)]. Unpublished Masters' Thesis, Bartın University, Bartın. 
İnal, S, Evin, İ., \& Saracoğlu A. S. (2005). Yabancı dil ve yabancı dil edinimi ile öğrenci yaklaşımları arasındaki ilişki [The relation between students' attitudes toward foreign language and foreign language achievement]. Dil Dergisi, (130), 38-53.

İzci, E., \& Koç, S. (2012). Öğretmen adaylarının yaşam boyu öğrenmeye ilişkin görüşlerinin değerlendirilmesi [Evaluation of teacher candidates' views on lifelong learning]. Adlyaman Üniversitesi Sosyal Bilimler Enstitüsü Dergisi, 9, 101-114.

Kaçar, I. G., \& Zengin, B. (2009). İngilizceyi yabancı dil olarak öğrenenlerin dil öğrenme ile ilgili inançları, öğrenme yöntemleri, dil öğrenme amaçları ve öncelikleri arasındaki ilişki: öğrenci boyutu [The relationship between learners of English as a foreign language, beliefs about language learning, learning methods, language learning goals and priorities: student dimension]. Journal of Language and Linguistic Studies, 5(1), 55-89.

Karaduman, A. (2015). Üniversite öğrencilerinin yaşam boyu öğrenme eğilimleri ile özyeterlik algıları arasındaki ilişki [The relationship between university students' lifelong learning tendencies and self-efficacy perceptions]. Unpublished Masters' Thesis. Bartın University Bartın.

Karatay, H., \& Kartallığlu, N. (2016). Yabancı dil olarak Türkçe öğrenme tutumu ile dil becerileri edimi arasındaki ilişki [The relationship between learning Turkish as a foreign language attitude and language skills acquisition]. Abant İzzet Baysal Üniversitesi Sosyal Bilimler Enstitüsü Dergisi, 16(4), 203-213.

Kazazoğlu, S. (2011). Anadili ve yabancı dil derslerine yönelik tutumun akademik başarıya etkisi [The effect of attitude towards mother tongue and foreign language lessons on academic success]. Unpublished Doctoral Dissertation, Ankara University, Ankara.

Kılıç, Ç. (2014). Öğretmen adaylarının yaşam boyu öğrenmeye yönelik algıları [Pre-service teachers' perceptions of lifelong learning]. Eğitim ve Öğretim Araștırmaları Dergisi, 3(4), 79-87.

Kılıç, H. (2015). İlköğretim branş öğretmenlerinin bireysel yenilikçilik düzeyleri ve yaşam boyu öğrenme eğilimleri (Denizli ili örneği) [Primary school branch teachers' individual innovativeness levels and lifelong learning tendencies (Denizli province example)]. Masters' Thesis, Pamukkale University, Denizli.

Kılıç, N., \& Taşpınar, M. (2017). Halk Eğitimi Merkezi Öğretmenlerinin Yaşam Boyu Öğrenme Eğilimleri [Lifelong Learning Tendencies of Public Education Center Teachers]. Journal of Research in Education and Teaching, 6(2), 14-25.

Kizıltan, N., \& Atlı, I. (2013). Turkish young language learners' attitudes towards English. Hacettepe Üniversitesi Eğitim Fakültesi Dergisi, 28(2), 266-278.

Kozikoğlu İ., \& Altunova N. (2018) Öğretmen adaylarının 21. yüzyıl becerilerine ilişkin öz-yeterlik algllarının yaşam boyu öğrenme eğilimlerini yordama gücü [The power of teacher candidates' self-efficacy perceptions of 21st century skills to predict lifelong learning tendencies]. Yükseköğretim ve Bilim Dergisi, 8, 1-15.

Memduhoğlu, H. B., \& Kozikoğlu, İ. (2015). Üniversite öğrencilerinin yabancı dil derslerine ilişkin tutumları [University students' attitudes towards foreign language courses]. Dicle Üniversitesi Ziya Gökalp Eğitim Fakültesi Dergisi, 24, 184202.

Selçuk, E. (1997). İngilizce dersine karsı tutum ile bu dersteki akademik başarı arasındaki ilişki [The relationship between attitude towards English lesson and academic achievement in this lesson]. Unpublished Masters' Thesis. Abant İzzet Baysal University, Bolu. 
Tok, H. (2010). Üniversite öğrencilerinin İngilizce dersine ilişkin duyuşsal tutumlarının bazı değişkenlere göre incelenmesi [Examination of affective attitudes of university students towards English lessons according to some variables]. Milli Eğitim Dergisi, 185, 90-109.

Toprak, M., \& Erdoğan, A. (2012). Yaşam boyu öğrenme: Kavram, politika, araçlar ve uygulama [Lifelong learning: Concept, policy, tools and practice]. Journal of Higher Education and Science, 2(2), 69-91.

Yaman, F., \& Yazar, T. (2015). Öğretmenlerin yaşam boyu öğrenme eğilimlerinin incelenmesi (Diyarbakır ili örneği) [Investigation of teachers' lifelong learning tendencies (Diyarbakır province example)]. Kastamonu Eğitim Dergisi, 23(4), 1553-1566. 
Ethics committee approval for this study was obtained from the Ethics Committee of Sakarya University Rectorate, dated 27/02/2018 and numbered 81. 